\title{
Expression of a highly active $\beta$-glucosidase from Aspergillus niger AS3.4523 in Escherichia coli and its application in gardenia blue preparation
}

Shuai Hao, Yuanpu Liu, Yu Qin, Lei Zhao, Jiawen Zhang, Tingting Wu, Baoguo Sun and Chengtao Wang*

\begin{abstract}
Purpose: Gardenia blue is one of the natural food additives used in East Asia for many years. Its biosynthesis relies on a key rate-limiting cellulase: $\beta$-glucosidase (BGL), which mainly exists in Aspergillus niger (A. niger) cells. The purpose of this study was to obtain active $\beta$-glucosidase by cell engineering method and applied to gardenia blue synthesis, which would help to promote the application and reduce the cost of $\beta$-glucosidase and gardenia blue.

Methods: A. niger was identified based on 185 rRNA gene sequencing. $\beta$-Glucosidase gene was cloned and expressed based on PCR and prokaryotic expression. The enzyme activity of $\beta$-glucosidase was measured based on $p$-nitrophenyl- $\beta$-D-glucopyranoside method.

Results: An A. niger isolate (AS3.4523) was identified from soil. The $\beta$-glucosidase gene of AS3.4523 was cloned and sequenced, which encoded a new type of $\beta$-glucosidase mutant containing two specific amino acid substitutions (Asp154Gly and Ser163Pro). Prokaryotic expression of wild-type $\beta$-glucosidase in Escherichia coli BL21 showed low cellulase activity $(0.29 \pm 0.13 \mathrm{U} / \mathrm{mL})$. However, after removing its signal peptide, the $\beta$-glucosidase of $A$. niger AS3.4523 exhibited extremely higher activity $(25.88 \pm 0.45 \mathrm{U} / \mathrm{mL})$ compared with wild type $\beta$-glucosidase $(12.59 \pm$ $1.07 \mathrm{U} / \mathrm{mL})$ or other A. niger strains M85 (3.61 $\pm 0.24 \mathrm{U} / \mathrm{mL})$ and CICC2041 (4.36 $\pm 0.76 \mathrm{U} / \mathrm{mL})$. Furthermore, recombinant $\beta$-glucosidase was applied to geniposide hydrolysis, and gardenia blue pigment was successfully synthesized with the reaction of genipin and Lys.

Conclusions: This work has discovered a new type of highly active $\beta$-glucosidase and provided a theoretical basis for large-scale producing $\beta$-glucosidase, which lays a brand-new foundation for gardenia blue preparation with high efficiency and low cost.
\end{abstract}

Keywords: Aspergillus niger, Enzyme activity, Gardenia pigments, Prokaryotic expression

\section{Introduction}

Gardenia blue, also called genipin blue, is one of the natural food additives used in East Asia for many years. It has been widely used in food and printing industry due to its excellent coloring property. Further investigation

\footnotetext{
* Correspondence: ctwangbtbu@163.com

Beijing Advanced Innovation Center for Food Nutrition and Human Health, Beijing Engineering and Technology Research Center of Food Additives,

Beijing Technology and Business University, No.11 Fucheng Road, Haidian District, Beijing 100048, China
}

on the preparation of gardenia blue is of great significance for its application.

The preparation of gardenia blue has been studied for years. The substrate of gardenia blue synthesis is geniposide, the principle iridoid glucoside in the fruit of Gardenia jasminoides Ellis (Yang et al. 2012). Geniposide could be transformed into genipin by hydrolyzing with $\beta$-glucosidase (Fujikawa et al. 1987; Xu et al. 2008). Genipin then reacts with amino acids to generate natural blue pigments (Fig. S1) (Cho et al. 2006). In this process, $\beta$-glucosidase

(c) The Author(s). 2020 Open Access This article is licensed under a Creative Commons Attribution 4.0 International License, which permits use, sharing, adaptation, distribution and reproduction in any medium or format, as long as you give appropriate credit to the original author(s) and the source, provide a link to the Creative Commons licence, and indicate if changes were made. The images or other third party material in this article are included in the article's Creative Commons licence, unless indicated otherwise in a credit line to the material. If material is not included in the article's Creative Commons licence and your intended use is not permitted by statutory regulation or exceeds the permitted use, you will need to obtain permission directly from the copyright holder. To view a copy of this licence, visit http://creativecommons.org/licenses/by/4.0/. 
(EC 3.2.1.21; BGL) is the key rate-limiting cellulase to transform geniposide into genipin, which determines the synthesis of gardenia blue (Yang et al. 2011). Since discovered in bitter almond in 1837, $\beta$-glucosidase was found to be widely present in kinds of microorganisms including Aspergillus, bacteria, and Saccharomyces (Kitagawa et al. 2010; Maki et al. 2013; You et al. 2010). Among these, Aspergillus niger (A. niger) is one of the most efficient producers of $\beta$-glucosidase (Sternberg et al. 1977). However, extracting $\beta$-glucosidase directly from $A$. niger was costly, which would greatly restrict the application of $\beta$ glucosidase and increase the cost of gardenia blue preparation. Nowadays, with the development of molecular biology and protein engineering technology, investigators have focused on producing the active $A$. niger $\beta$-glucosidase by using heterologous system, which significantly enhances the yield and reduces the cost of enzymes (Ali et al. 2015; Fang et al. 2014) and also provides new approaches to preparation of natural pigments.

Several studies have reported on the heterologous expression of $\beta$-glucosidase. Early in 2000, Dan et al. expressed recombinant $\beta$-glucosidase in Saccharomyces cerevisiae and Pichia pastoris and obtained high levels of secreted enzymes. Ali et al. (2015) expressed GH3 family $\beta$-glucosidase in P. pastoris GS115 and transformed cellulosic biomass to reducing sugars. Fang et al. (2014) successfully cloned and expressed activated xylanase from A. niger in $P$. pastoris. However, all the abovementioned studies focused on expressing $A$. niger $\beta$-glucosidase in eukaryotes, which had relatively long expression period and low expression efficiency. Particularly, Dan et al. (2000) attempted to express recombinant $\beta$-glucosidase in Escherichia coli $(E$. coli), but no apparent $\beta$-glucosidase activity was found in crude extracts.

The objective of the present study was to express highly active $A$. niger $\beta$-glucosidase in a prokaryotic expression system and apply it to gardenia blue preparation. In this work, an A. niger AS3.4523 was identified, which contained a new type of $\beta$-glucosidase mutant. The active AS3.4523 $\beta$-glucosidase was successfully expressed in E. coli and applied to gardenia blue preparation. In this sense, this study has provided an efficient way for $\beta$-glucosidase expression and gardenia pigment synthesis.

\section{Materials and methods}

\section{Isolation and identification of Aspergillus niger}

The fungal strain was isolated from soil samples collected from Beijing Technology and Business University, China (N39 $\left.55^{\prime} 27.60^{\prime \prime}, \mathrm{E} 116^{\circ} 18^{\prime} 31.81^{\prime \prime}\right)$. Soil was collected randomly 10-15 $\mathrm{cm}$ beneath the surface using spatula and were packed in sterile poly bags. Czapek's medium was used for isolation of fungal strain, and its composition was as follows $(\mathrm{g} / \mathrm{L})$ : sucrose $30, \mathrm{NaNO}_{3} 3$,
$\mathrm{K}_{2} \mathrm{HPO}_{4} 1, \mathrm{MgSO}_{4} \cdot 7 \mathrm{H}_{2} \mathrm{O} 0.5, \mathrm{KCl} 0.5, \mathrm{FeSO}_{4}$ 0.01, agar 20 . The strain which produced high-activity $\beta$-glucosidase was selected for further identification. Total DNA of strain was isolated in DNA extraction reagent according to the manufacturer's protocol (TIANGEN, Beijing, China). 18S rRNA encoding gene was amplified by PCR using universal primers (NS1: 5'-GTAGTCATATGCTTGTCTC-3', NS8: 5' -TCCGCAGGTTCACCTACGGA-3'). The amplification product was sequenced and analyzed by comparison with $A$. niger species in GeneBank.

\section{RNA extraction, reverse transcription, and PCR}

Total RNA was isolated from $A$. niger AS3.4523 by homogenizing in Trizol reagent according to the manufacturer's protocol (Invitrogen, Carlsbad, CA, USA). The quantity and quality of RNA was measured by spectrophotometer (Eppendorf, Germany), and cDNA was synthesized using M-MLV reverse transcriptase (Takara, Dalian, China). The $\beta$-glucosidase $(b g l)$ gene was obtained by PCR amplification using specific primers (sense: 5'-CGGGATCCATGAGG TTCACTTTGA-3', anti-sense: 5'-CCGCTCGAGTTAGT GAACAGTAGGCA-3') encoding the BamH1 and Sac1 restriction sites. The amplified product was sequenced by Invitrogen (Thermo Fisher, Waltham, MA, USA) and analyzed later.

\section{Enzyme assay}

The activity of $\beta$-glucosidase was determined by the $p$ nitrophenyl- $\beta$-D-glucopyranoside (pNPG, Sigma, MO, USA) method. The crude enzyme was extracted using ultrasonic method. Briefly, the A. niger AS3.4523 was cultured in $50 \mathrm{~mL}$ liquid fermentation medium (3\% bran, $1 \%$ glucose, $1 \%$ peptone, $1 \% \mathrm{KH}_{2} \mathrm{PO}_{4}, 0.2 \%$ $\mathrm{MgSO}_{4}$, and $0.2 \%$ tween) in a $250-\mathrm{mL}$ triangular flask at $30{ }^{\circ} \mathrm{C}$ with $200 \mathrm{rpm} / \mathrm{min}$ shaking for $5-7$ days. Then, the A. niger AS3.4523 was collected through centrifugation at $9500 \mathrm{rpm} / \mathrm{min}$ for $10 \mathrm{~min}$. The cell precipitate was resuspended in PBS, followed by sonication in an ice bath for $10 \mathrm{~s}$ with a $45 \mathrm{~s}$ interval between each ultrasonic cycle until clarified. Then, $0.1 \mathrm{~mL}$ crude extract was added into $1 \mathrm{~mL} 0.05 \mathrm{mM}$ citrate buffer solution $(\mathrm{pH}$ 5.0) for $10 \mathrm{~min}$ at $50{ }^{\circ} \mathrm{C}$. The pNPG solution $(5 \mathrm{mM}, 0.9$ $\mathrm{mL}$ ) was preheated for $10 \mathrm{~min}$ at $50{ }^{\circ} \mathrm{C}$, followed by mixing with the treated crude enzyme for $10 \mathrm{~min} . \mathrm{NaCO}_{3}$ was added to the mixtures to terminate the reaction and measured the amount of $p$-nitrophenol released at 400 $\mathrm{nm}$. The content of $p$-nitrophenol was calculated according to the $p$-nitrophenol standard curve. The concentration range of the $p$-nitrophenol standard curve was from 0.02 to $0.2 \mathrm{mg} / \mathrm{mL}$. One unit of enzyme activity is defined as the amount of enzyme which released one $\mu \mathrm{mol}$ of $p$-nitrophenol per min under the reaction conditions above (Hong et al. 2009; Kubicek 1982). 


\section{Vector construction and prokaryotic expression}

The $b g l \mathrm{cDNA}$ and pET28a were subjected to BamH1 and Sac1 restriction digestion and inserted into the BamH1/ Sac1 site of pET28a (pET28a-bgl) followed by transformation in $E$. coli BL21. Positive colonies containing the $b g l$ cDNA were detected by colony PCR method and further confirmed by enzyme restriction and sequence analysis. Recombinant BGL was expressed according to the manufacturer's protocol. Briefly, BL21-pET28a- $b g l$ was grown in $25 \mathrm{~mL}$ Luria-Bertani (LB) medium (1\% tryptone, 1\% $\mathrm{NaCl}$, and $0.5 \%$ yeast extract) at $37{ }^{\circ} \mathrm{C}$ and $200 \mathrm{rpm}$ until the optical density $600\left(\mathrm{OD}_{600}\right)$ of 0.6 to 1.0 , followed by isopropyl- $\beta$-d-thiogalactoside (IPTG) addition at the inducing condition of $20^{\circ} \mathrm{C}$ and $150 \mathrm{rpm}$ for $16 \mathrm{~h}$. The culture supernatant and precipitate were collected by centrifugation, respectively. The bacteria protein was extracted with ultrasonication. Briefly, the suspension was sonicated in an ice bath for $10 \mathrm{~s}$ with a $45 \mathrm{~s}$ interval between each ultrasonic cycle until clarified, followed by centrifugation for $30 \mathrm{~min}$ at $12,000 \mathrm{rpm}$. The supernatant protein was stored before use. Then, 12\% SDS-PAGE was used to analyze the expression results. Proteins were visualized by Coomassie Brilliant Blue R-250 staining. The protein concentration was determined by Braford assay using bovine serum albumin as a standard.

\section{Renaturation of inclusion bodies}

The inclusion bodies were washed with $1 \%$ Triton X-100 for 3 times, followed by dissolving with urea buffer $(8 \mathrm{M}$ urea, $0.1 \mathrm{M}$ Tris- $\left.\mathrm{HCl}, 0.1 \mathrm{M} \mathrm{Na}_{2} \mathrm{HPO}_{4}, \mathrm{pH} 8.0\right)$ at $4{ }^{\circ} \mathrm{C}$ overnight. The dissolved solution was purified by $\mathrm{Ni}$ NTA sepharose. Briefly, the Ni-NTA sepharose was equilibrated with equilibrium buffer $(8 \mathrm{M}$ urea, $0.1 \mathrm{M}$ Tris- $\mathrm{HCl}, 0.1 \mathrm{M} \mathrm{Na}_{2} \mathrm{HPO}_{4}, \mathrm{pH}$ 8.0). After sample absorption, Ni-NTA sepharose was washed with washing buffer ( $8 \mathrm{M}$ urea, $0.1 \mathrm{M}$ Tris- $\mathrm{HCl}, 0.1 \mathrm{M} \mathrm{Na}_{2} \mathrm{HPO}_{4}, \mathrm{pH}$ 6.3), followed by sample elution with elution buffer ( $8 \mathrm{M}$ urea, $0.1 \mathrm{M}$ Tris- $\mathrm{HCl}, 0.1 \mathrm{M} \mathrm{Na}_{2} \mathrm{HPO}_{4}, \mathrm{pH}$ 4.0). The purified $\beta$-glucosidase was renatured in renaturation buffer $\left(0.1 \mathrm{M}\right.$ Tris- $\mathrm{HCl}, 0.1 \mathrm{M} \mathrm{Na}_{2} \mathrm{HPO}_{4}, 3 \mathrm{mM}$ reduced glutathione, $0.3 \mathrm{mM}$ oxidized glutathione, and $5 \%$ glycerinum, $\mathrm{pH}$ 8.0) for $16 \mathrm{~h}$. After renaturation, the sample was desalted with G25 gel column.

\section{Preparation of gardenia blue}

One hundred milligrams geniposide (Weikeqi Biological Technology, Sichuan, China, $\geq 98 \%$ purity) and recombinant $\beta$-glucosidase $(8 \%, \mathrm{v} / \mathrm{v})$ were dissolved in $10 \mathrm{~mL}$ citrate buffer solution and incubated at $55{ }^{\circ} \mathrm{C}$ for $7 \mathrm{~h}$. Glucose production was analyzed by high performance liquid chromatography (HPLC) to measure the catalytic effect. Briefly, the type of the chromatographic column used was HPX-87H $(300 \mathrm{~mm} \times 7.8 \mathrm{~mm})$ (Bio-Rad, Hercules, CA, USA). The mobile phase was $\mathrm{H}_{2} \mathrm{SO}_{4}(5$ $\mathrm{mmol} / \mathrm{L}$ ), and the flow rate was $0.5 \mathrm{~mL} / \mathrm{min}$ with an injection volume of $20 \mu \mathrm{L}$. The glucose was analyzed according to the standard curve. The concentration range of the glucose standard curve was from 0.2 to $2.0 \mathrm{mg} /$ $\mathrm{mL}$. Ten millimolar genipin was reacted with $10 \mathrm{mM}$ amino acids in $100 \mathrm{~mL}$ distilled water at $80^{\circ} \mathrm{C}$ for $10 \mathrm{~h}$, followed by boiling water bath for $20 \mathrm{~min}$. The reaction solution was centrifuged at $9500 \mathrm{rpm}$ for $10 \mathrm{~min}$. The content of gardenia blue was measured by $\mathrm{OD}_{\max }$ (Multiskan Sky, Thermo Fisher). The hue (L, a, and b value) of pigments was measured by colorimeter ( $\mathrm{CHN}$ Spec, Hangzhou, China).

\section{Statistical analysis}

The experimental data were shown as mean \pm standard deviation (SD), the significance of difference was analyzed according to the two-tailed Student's $t$ test, and the statistically significant was determined when $p<$ $0.05{ }^{(*)}$ or $p<0.01{ }^{(* *)}$.

\section{Results and discussion Identification of Aspergillus niger}

The experimental strain was previously isolated from soil around Beijing Technology and Business University. The genomic DNA of strain was extracted from the isolated strain. The $18 \mathrm{~S}$ rRNA encoding gene was amplified and obtained based on genomic DNA template using universal primers (Fig. 1a). Sequencing and bioinformatics analysis of $18 \mathrm{~S}$ rRNA encoding gene indicated that the experimental strain belonged to A. niger (Fig. 1b), and it was named as A. niger AS3.4523 in this study.

\section{Analysis of $\beta$-glucosidase gene in A. niger AS3.4523}

A specific target gene from $A$. niger AS3.4523 was amplified and obtained (Fig. 2a) by using primers targeting $\beta$ glucosidase gene (GQ471881.1) in the database. The open reading frame (ORF, $2583 \mathrm{bp}$ ) and amino acid sequence (860 amino acids) are shown in Fig. S2 and S3, respectively. Sequence comparison showed that it shared high homology with $b g l$ gene GQ471881.1. Importantly, four substitutions (A713G, T739C, T744C, and C807T) were discovered in target gene (Fig. 2b). As a result, two specific amino acids were changed (Asp154Gly and Ser163Pro) in the corresponding protein (Fig. 2c), indicating a $\beta$ glucosidase mutant existed in A. niger AS3.4523. It is worth mentioning that Gräbnitz et al. (1991) reported that the active site of $\beta$-glucosidase in Clostridium thermocellum was located within approximately 200 amino acids of the $\mathrm{N}$ terminus of the protein, possibly suggesting the mutated amino acids (Gly154 and Pro163 are both located in the $\mathrm{N}$-side of protein) might have an effect on its enzymatic activity. To confirm the hypothesis, pNPG assay was performed to analyze the enzymatic activity in crude enzyme extract. Interestingly, compared with A. niger GQ471881.1 
A

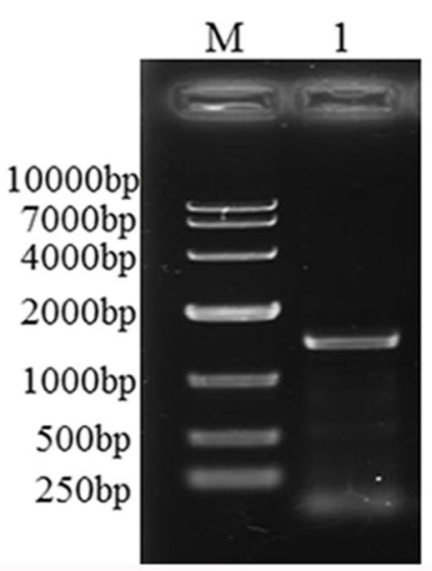

B

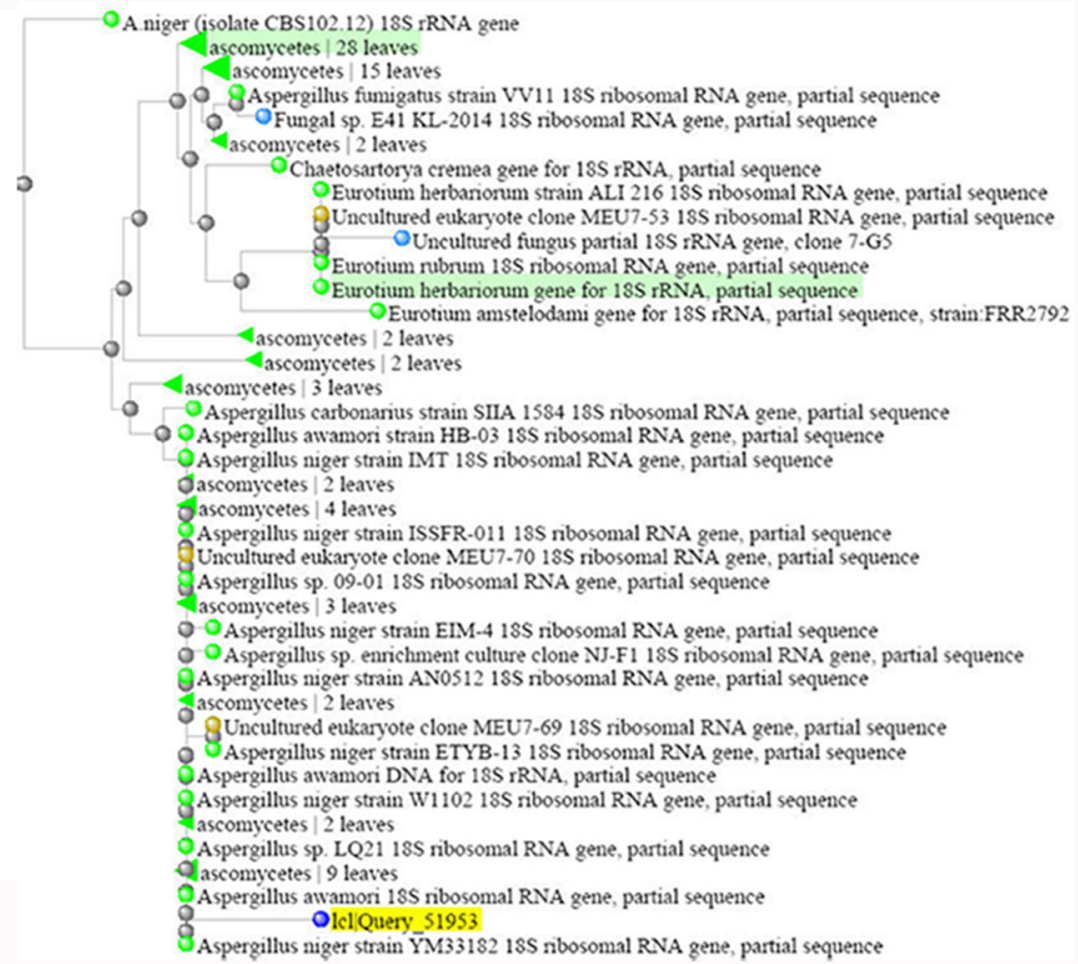

Fig. 1 Identification of experimental strain. a Agarose gel electrophoresis analysis of 185 rRNA encoding gene of experimental strain, respectively. M, DNA marker. b Bioinformatics identification of experimental strain using BLAST

$(6.15 \pm 0.15 \mathrm{U} / \mathrm{mL})$ and other two types of $A$. niger strains M85 $(3.61 \pm 0.24 \mathrm{U} / \mathrm{mL})$ and CICC2041 $(4.36 \pm 0.76 \mathrm{U} /$ $\mathrm{mL}$ ) (the BGL protein sequences in A. niger M85 and CICC2041 are shown in Fig. S4 and S5, respectively), $A$. niger AS3.4523 possessed a higher enzyme activity (13.19 \pm $0.27 \mathrm{U} / \mathrm{mL}$, Fig. $2 \mathrm{~d}$ ). Meanwhile, the extracellular activity of $\beta$-glucosidase was also detected, and the results showed no enzyme activity in the medium (data not shown), suggesting that $\beta$-glucosidase is an intracellular enzyme in $A$. niger AS3.4523. Taken together, these findings revealed that a new transcript of $b g l$ gene in A. niger AS3.4523 could express $\beta$-glucosidase with higher activity.

\section{Prokaryotic expression of $\beta$-glucosidase from $A$. niger AS3.4523 in E. coli}

To efficiently express $\beta$-glucosidase of $A$. niger AS3.4523, a recombinant plasmid pET28a-bgl was constructed and transformed into $E$. coli BL21. $\beta$-Glucosidase was induced by IPTG. Figure $3 \mathrm{a}$ indicated that the expression of $\beta$ glucosidase was dose-dependent on IPTG concentration. High concentration of IPTG $(0.5,0.6$, and $0.7 \mathrm{mM}$, marked by arrows) induced high amount of $\beta$-glucosidase; however, most of which were present in inclusion bodies. On the other hand, $0.3 \mathrm{mM}$ IPTG could induce high amount of soluble $\beta$-glucosidase (marked by arrows). However, the pNPG assay detected no obvious $\beta$-glucosidase activity in crude extract $(0.29 \pm 0.13 \mathrm{U} / \mathrm{mL}$, Fig. $3 b)$.

So far, great efforts have been made to enhance the $\beta$ glucosidase and other cellulase activity for further utilization. While most studies focused on microorganisms' genetic manipulation (Cunha et al. 2013) or condition optimization of fermentation process (Jabbour et al. 2013; Yan and Wu 2011, Yan and Wu 2012, Yan et al. 2012, Yan and Wu 2013) to enhance the $\beta$-glucosidase enzymatic activity, few studies reported the relationship between its activity and signal peptide. In the present study, the amino acid sequence of $\beta$-glucosidase from $A$. niger AS3.4523 (Fig. S3) was submitted to the protein signal peptide prediction website SignalP 4.1 Server (http://www.cbs.dtu.dk/services/SignalP/). The analysis result (Fig. S6) indicated that the signal peptide was the sequence containing 19 amino acids after initiation methionine. Figure 3c showed that the 57 nucleotides after initiation codon (highlighted by underline) translated the signal peptide of $\beta$-glucosidase. Subsequently, the mutant recombinant plasmid pET28a- $\Delta$ SP was constructed, 


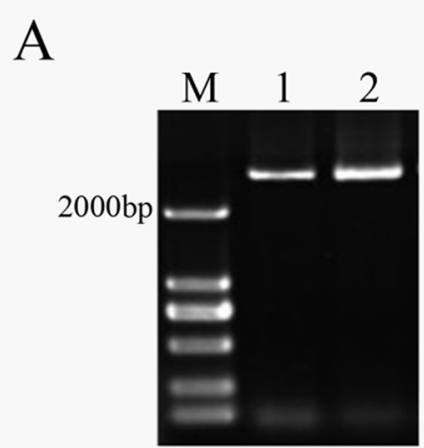

B

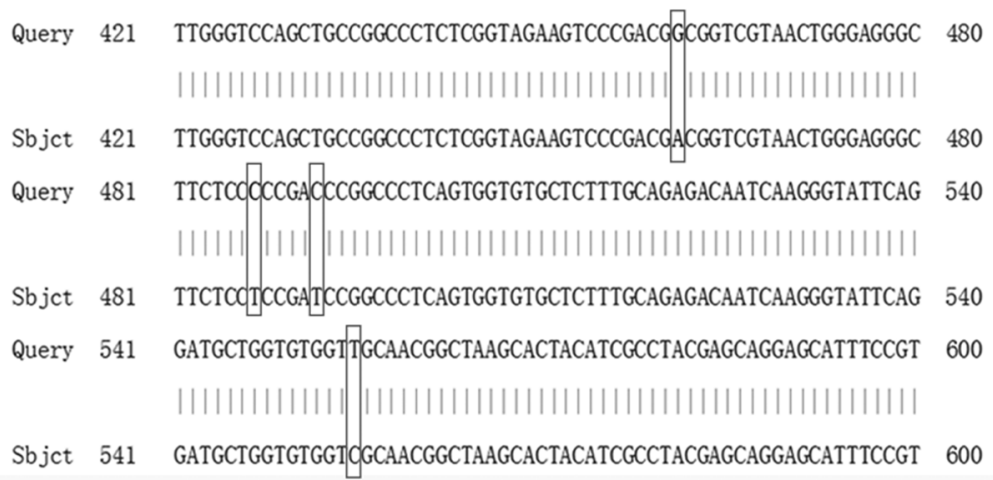

$\mathrm{C}$

Query 121 AYLRGQAMGQEFSDKGADIQLGPAaGPLGRPDGGRNWEGFSPDPALSGVLFAETIKGIQ 180

Sbjct 121 AYLRGQAMGQEFSDKGADIQLGPAAGPLGRSPDGRNIEGFSSDPALSGVLFAETIKGIQ 180

Fig. 2 Analysis of $\beta$-glucosidase gene in A. niger AS3.4523. a RT-PCR analysis of bg/transcript in A. niger AS3.4523. M, DNA marker; lanes 1 and 2 represent two independent experiments. b Partial sequence analysis of $\mathrm{bgl}$ gene in A. niger AS3.4523. The black boxes showed four mutated nucleotides. c Partial protein sequence of $\beta$-glucosidase in A. niger AS3.4523. The black boxes showed two mutated amino acids. $\mathbf{d} \beta$-glucosidase activity assay in A. niger AS3.4523 compared with M85, CICC2041, and GQ471881.1. Bars represent mean \pm SD $(n=3) .{ }^{* *} p<0.01$

which did not contain the signal peptide sequence, followed by IPTG induction in BL21. As shown in Fig. $3 \mathrm{~d}$, the soluble $\beta$-glucosidase without signal peptide was successfully expressed using $0.3 \mathrm{mM}$ IPTG (lane 4 and 8 , marked by arrows). The enzymatic activity of crude extract was analyzed using pNPG assay. Surprisingly, after removing the signal peptide, the activity of $\beta$ glucosidase increased to $35.88 \pm 0.45 \mathrm{U} / \mathrm{mL}$, which was even higher than wild-type $\beta$-glucosidase $(12.59 \pm 1.07 \mathrm{U} /$ $\mathrm{mL}$ ) in A. niger AS3.4523 (Fig. 3e). Consistent with A. niger AS3.4523, no extracellular $\beta$-glucosidase activity was detected in medium (data not shown). It is worth mentioning that $\mathrm{Hu}$ et al. (1993) had removed the signal peptide of human prourokinase and expressed the protein in E. coli. They discovered that both the supernatant and inclusion bodies had biological activities. Strikingly, it has been reported that the arresten protein, a type of angiogenesis inhibitor, exerted high level and biological activities after expressed through pBV200 prokaryotic expression plasmid in E. coli (Zheng et al. 2006). These results have provided strong theoretical support for our research. To the best of our knowledge, the present work is the first report on prokaryotic expression of highly active $\beta$-glucosidase from $A$. niger, which has good application value in various fields.

To further investigate whether the inclusion bodies exerted high $\beta$-glucosidase activity, the precipitate proteins were dissolved, purified using Ni-NTA sepharose, followed by renaturation and desalting. Moreover, the signal peptide of precipitate proteins was also removed. Figure S7 showed the SDS-PAGE of purification process, indicating that the precipitate $\beta$-glucosidase was successfully purified. Then, the activity of renatured $\beta$-glucosidase was measured using pNPG method. As shown in Fig. S8, the $\beta$-glucosidase activity of inclusion bodies was still low 


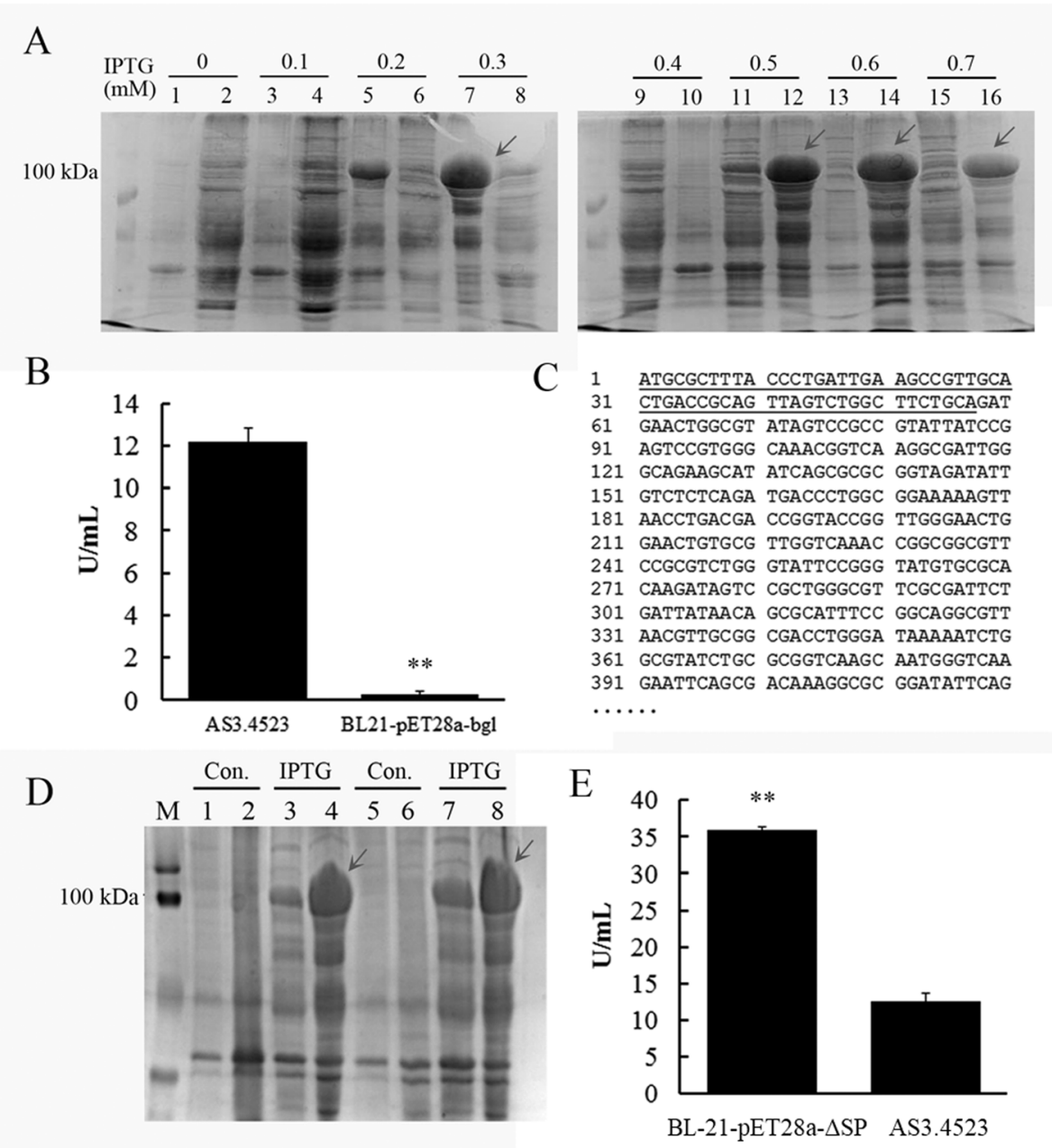

Fig. 3 Prokaryotic expression and enzymatic determination of $\beta$-glucosidase from A. niger AS3.4523 in E. coli. a SDS-PAGE results of prokaryotic expression of $\beta$-glucosidase. Lanes 1, 3, 5, 7, 9, 11, 13, and 15 represent supernatant proteins; lanes 2, 4, 6, 8, 10, 12, 14, and 16 represent precipitate proteins. The recombinant $\beta$-glucosidase was marked by arrow. $\mathbf{b}$ pNPG assay on enzymatic activity of wild-type $\beta$-glucosidase and recombinant $\beta$-glucosidase. c Signal peptide sequence of $\beta$-glucosidase (marked by underline). d Prokaryotic expression of $\beta$-glucosidase without signal peptide using 0.3 mM IPTG inducing. Lanes 1, 3, 5, and 7 represent precipitate proteins; lanes 2, 4, 6, and 8 represent supernatant proteins. Con., no IPTG groups. The recombinant $\beta$-glucosidase was marked by arrows. e PNPG assay on enzymatic activity of wild type and prokaryotic expressed $\beta$-glucosidase without signal peptide. BL21-pET28a- $\Delta$ SP represents recombinant plasmid without bg/ signal peptide. Bars represent mean $\pm \mathrm{SD}(n=3) .{ }^{*} p<0.05 ;{ }^{* *} p<0.01$

after renaturation $(0.164 \pm 0.053 \mathrm{U} / \mathrm{mL})$, similar with that of supernate $\beta$-glucosidase $(0.238 \pm 0.013 \mathrm{U} / \mathrm{mL})$. Interestingly, after removing the signal peptide, the $\beta$-glucosidase activity had increased to $10.265 \pm 1.987 \mathrm{U} / \mathrm{mL}$, which was basically the same with that in AS3.4523 but still not as high enough as that of supernate $\beta$-glucosidase without signal peptide $(36.219 \pm 1.543 \mathrm{U} / \mathrm{mL})$. We speculated that the renaturation process might not fully restore the activity of the enzyme, which resulted in the decreased $\beta$-glucosidase activity in inclusion bodies. Taken together, we had successfully expressed recombinant $A$. niger AS3.4523 $\beta$-glucosidase with high activity in $E$. coli. expression system.

\section{Preparation of gardenia blue pigments by using recombinant $\beta$-glucosidase}

As recombinant $\beta$-glucosidase with high activity was successfully expressed in E. coli, it was further used for gardenia blue synthesis. Recombinant $\beta$-glucosidase extract was incubated with geniposide to generate genipin. The glucose production was analyzed by HPLC. The HPLC results of glucose standard and geniposide hydrolysate are shown in Fig. S9, suggesting that the production of glucose could be used to indirectly assess the production of genipin and catalytic process. Later, 6 kinds of amino acids (Val, Ala, Phe, Met, Lys, and Arg) were selected to react with genipin at $80{ }^{\circ} \mathrm{C}$ for $10 \mathrm{~h}$. 
Figure 4a displays the pigments synthesized by different amino acids. Table 1 shows the essential parameters of different pigments. As we can see, Val, Phe, Met, Arg, and Ala could generate purple pigments. Particularly, Lys was the optimal amino acid in this study because it could form blue pigment when reacted with genipin, which revealed that gardenia blue was successfully prepared by using recombinant $\beta$-glucosidase.

The effects of reaction conditions on gardenia blue production were further investigated in our work. The production yield of pigments was indicated by $\mathrm{OD}_{\max }$ value of gardenia blue. As shown in Fig. $4 \mathrm{~b}$, the production of gardenia blue reached maximum $\left(\mathrm{OD}_{584} 0.72 \pm\right.$ 0.02 ) when molar ratio of Lys and geniposide was 3:1. In addition, citric acid also had effect on gardenia blue synthesis, and the optimal molar ratio of citric acid and geniposide was 6:1 (Fig. 4c, $\mathrm{OD}_{584} 0.78 \pm 0.02$ ). Figure $4 \mathrm{~d}$ showed the effects of temperature and time on preparation of pigments. As we can see, the yields of gardenia blue increased as the reaction time and temperature increased. The gardenia blue production remained stable after $28 \mathrm{~h}$ at $80{ }^{\circ} \mathrm{C}$, which was the optimal reaction condition in our study $\left(\mathrm{OD}_{584} 0.91 \pm 0.01\right)$. It was worth mentioning that Cho et al. (2006) had produced gardenia blue pigments from geniposide by using one-step enzymatic method and investigated the effect of reaction temperature on pigment yield. Their results showed that the maximum of pigment production was about $\mathrm{OD}_{\max }$ 0.62, which was lower than that in our work. In addition, Xiao et al. (2002) and Li et al. (2001) also investigated the optimal synthesis process of gardenia blue pigments. They obtained the pigment yield of $\mathrm{OD}_{\max } 0.882$ and $\mathrm{OD}_{\max } 0.8$, respectively, which was slightly lower than our results. Nevertheless, the yield of gardenia blue in our study only slightly increased compared with others' work, which might be due to other conditions in preparation process. In this case, we are also planning to increase the yield of gardenia blue by optimizing the producing process in our future work.

\section{Conclusion}

In this work, a new $A$. niger isolate (AS3.4523) was identified from soil, which contained a new type of $\beta$ glucosidase mutant containing two specific amino acid substitutions (Asp154Gly and Ser163Pro) compared with A. niger BCRC31494. Enzymatic activity assay indicated that $\beta$-glucosidase from $A$. niger AS3.4523 exerted higher activity $(13.19 \pm 0.27 \mathrm{U} / \mathrm{mL})$ compared with $A$. niger strains M85 $(3.61 \pm 0.24 \mathrm{U} / \mathrm{mL})$ and CICC2041 $(4.36 \pm 0.76 \mathrm{U} / \mathrm{mL})$. Prokaryotic expressed AS3.4523 $\beta$ glucosidase without signal peptide exhibited extremely even higher activity $(35.88 \pm 0.45 \mathrm{U} / \mathrm{mL})$ than the wild
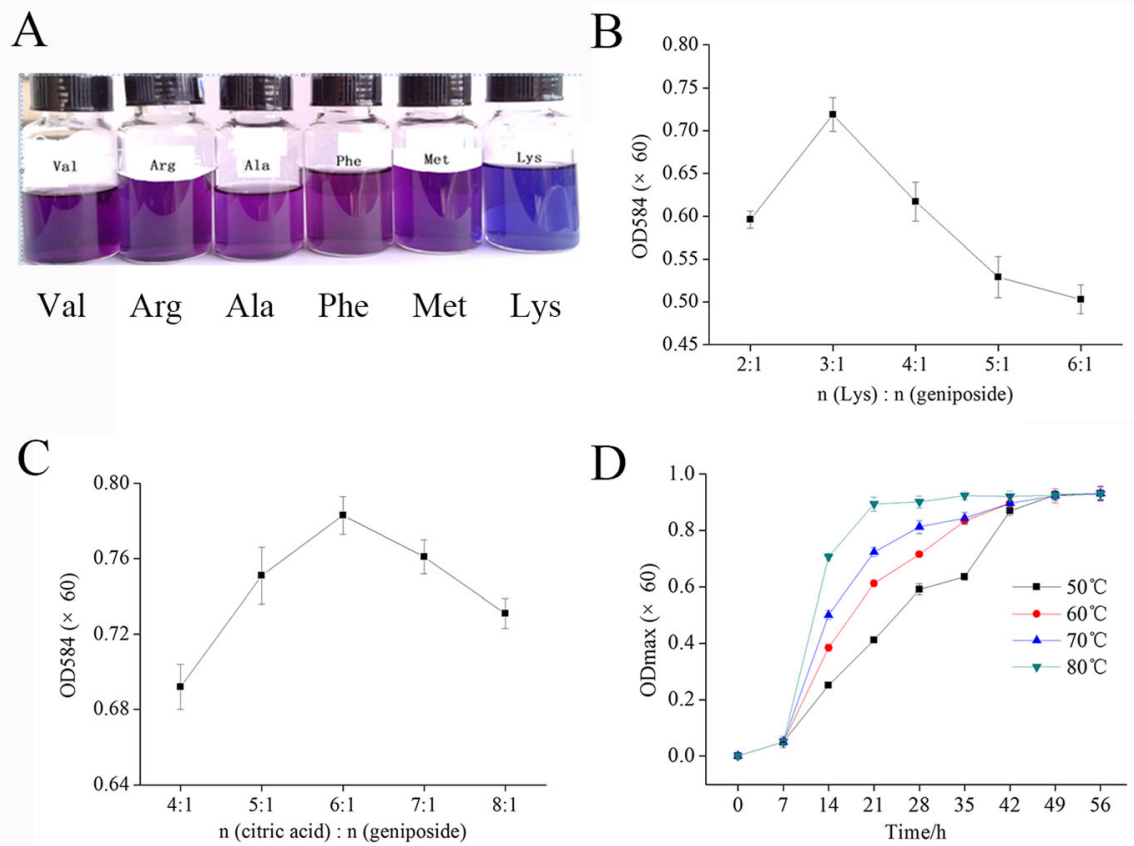

Fig. 4 Preparation of gardenia blue pigments by using recombinant $\beta$-glucosidase. a Photographs of gardenia pigments synthesized by reaction of genipin and 6 types of amino acids (Val, Ala, Phe, Met, Lys, and Arg). b Effect of Lys content on gardenia blue pigment production. c Effect of citric acid content on gardenia blue pigment production. $\mathbf{d}$ Effect of temperature and time on gardenia blue production. Bars represent mean \pm SD $(n=3)$ 
Table 1 Essential parameters of the pigments synthesized with different amino acids

\begin{tabular}{llllll}
\hline Amino acids & $\lambda \max (\mathrm{nm})$ & $\mathrm{L}^{\dagger}$ & $\mathrm{a}^{\ddagger}$ & $\mathrm{b}^{\S}$ & Color \\
\hline Val & 584 & 70.29 & 14.44 & -16.21 & Purple \\
Ala & 582 & 69.52 & 18.19 & -6.08 & Purple \\
Phe & 582 & 65.28 & 18.01 & -13.61 & Purple \\
Met & 586 & 66.81 & 14.84 & -20.24 & Purple \\
Lys & 584 & 71.33 & 9.93 & -12.53 & Blue \\
Arg & 588 & 71.57 & 15.78 & -16.91 & Purple
\end{tabular}

Note: ${ }^{\dagger}$ Represented the brightness of solution. The bigger of L's value, the brighter of the solution

${ }^{\ddagger}$ Represented red-green index. The bigger of a's value, the redder of the solution

${ }^{\S}$ Represented yellow-blue index. The smaller of b's value, the bluer of the solution

type. Furthermore, $\beta$-glucosidase was successfully applied to geniposide hydrolysis and gardenia blue preparation. Consequently, a highly active $\beta$-glucosidase from A. niger AS3.4523 was discovered and expressed in prokaryotic system, which provided a theoretical and application foundation for efficient preparation of gardenia blue pigments.

\section{Supplementary information}

Supplementary information accompanies this paper at https://doi.org/10. 1186/s13213-020-01576-7.

Additional file 1: Figure S1. Preparation of gardenia blue (genipin blue). Hydrolysis of glycosides extracted from the fruits of Gardenia jasminoides Ellis using $\beta$-glucosidase yields genipin. Reaction of genipin with amino acids leads to formation of gardenia blue (genipin blue) pigments. Figure S2. The open reading frame (ORF) of $\beta$-glucosidase gene of A. niger AS3.4523. The signal peptide sequence was marked by underline in red. Figure S3. Amimo acid sequence of $\beta$-glucosidase of A. niger AS3.4523. Figure S4. Amino acid sequence of $\beta$-glucosidase of A. niger M85. Figure S5. Amino acid sequence of $\beta$-glucosidase of $A$. niger CICC2041. Figure S6. Signal peptide analysis of $\beta$-glucosidase from A. niger AS3.4523 using prediction website SignalP 4.1 Server (http://www. cbs.dtu.dk/services/SignalP/). The result showed that the signal peptide cleavage site was between the 19th and 20th amino acids, indicating the signal peptide was the sequence containing 19 amino acids after initiation Met (corresponding to 57 nucleotides after initiation codon)

Figure S7. SDS-PAGE of purification process of inclusion bodies. Lane 1 represented SDS-PAGE of inclusion bodies $\beta$-glucosidase; Lane 2 represented SDS-PAGE of purified inclusion bodies $\beta$-glucosidase; Lane 3 represented SDS-PAGE of $\beta$-glucosidase after renaturation; Lane 4 represented SDS-PAGE of $\beta$-glucosidase without signal peptide after renaturation. Figure S8. pNPG assay on enzymatic activity of wild type, supernate and renatured precipitate $\beta$-glucosidase with or without signal peptide, respectively. Bars represent mean $\pm \mathrm{SD}(n=3)$. ${ }^{* *}, p<0.01$. Figure S9. HPLC analysis of glucose standard (A) and geniposide hydrolysate (B). The production of glucose could be used to indirectly assess the production of genipin and catalytic process.

\section{Authors' contributions}

The authors read and approved the final manuscript.

\section{Funding}

This study was supported by the National Natural Science Foundation of China (NSFC, No. 31701575, 31571801), National Key Research and
Development Program (No. 2016YFD0400502), and Beijing Municipal Science and Technology Project (No. Z171100002217019).

\section{Ethics approval and consent to participate}

This article does not contain any studies with human participants or animals performed by any of the authors.

\section{Consent for publication}

N/A. This article does not involve human participants.

\section{Competing interests}

The authors declare that they have no conflict of interest.

Received: 19 January 2020 Accepted: 24 April 2020

Published online: 19 May 2020

References

Ali N, Ting Z, Li HL, Xue Y, Gan LH, Liu J et al (2015) Heterogeneous expression and functional characterization of cellulose-degrading enzymes from Aspergillus niger for enzymatic hydrolysis of alkali pretreated bamboo biomass. Mol Biotechnol 57:859-867

Cho YJ, Kim SY, Kim J, Choe EK, Kim SI, Sin HJ (2006) One-step enzymatic synthesis of blue pigments from geniposide for fabric dyeing. Biotechnol Bioprocess Eng 11:230-234

Cunha ES, Hatem CL, Barrick D (2013) Insertion of endocellulase catalytic domains into thermostable consensus ankyrin scaffolds: effects on stability and cellulolytic activity. Appl Environ Microbiol 79:6684-6696

Dan S, Marton I, Dekel M, Bravdo BA, He S, Withers SG et al (2000) Cloning, expression, characterization, and nucleophile identification of family 3, Aspergillus niger beta-glucosidase. J Biol Chem 275:4973-4980

Fang W, Gao H, Cao YH, Shan AS (2014) Cloning and expression of a xylanase xynB from Aspergillus niger IA-001 in Pichia pastoris. J Basic Microbiol 54: S190-S199

Fujikawa S, Yokota T, Koga K, Kumada JI (1987) The continuous hydrolysis of geniposide to genipin using immobilized-glucosidase on calcium alginate cell. Biotechnol Lett 10:697-702

Gräbnitz F, Seiss M, Rucknagel KP, Staudenbauer WL (1991) Structure of the betaglucosidase gene bglA of Clostridium thermocellum. Sequence analysis reveals a superfamily of cellulases and beta-glycosidases including human lactase/phlorizin hydrolase. Eur J Biochem 200:301-309

Hong MR, Kim YS, Park CS, Lee JK, Kim YS, Oh DK (2009) Characterization of a recombinant $\beta$-glucosidase from the thermophilic bacterium Caldicellulosiruptor saccharolyticus. J Biosci Bioeng 108(1):36-40

Hu B, Li J, Yu W, Fang J (1993) Cloning of human prourokinase cDNA without the signal peptide and expression in Escherichia coli. Chin J Biotechnol 9:95-101

Jabbour D, Borrusch MS, Banerjee G, Walton JD (2013) Enhancement of fermentable sugar yields by alpha-xylosidase supplementation of commercial cellulases. Biotechnol Biofuels 6:58

Kitagawa T, Tokuhiro K, Sugiyama H, Kohda K, Isono N, Hisamatsu M et al (2010) Construction of a beta-glucosidase expression system using the multistresstolerant yeast Issatchenkia orientalis. Appl Microbiol Biotechnol 87:1841-1853

Kubicek CP (1982) $\beta$-Glucosidase excretion by Trichoderma pseudokoningii: correlation with cell wall bound $\beta$-1.3-glucanase activities. Arch Microbiol 132(4):349-354

Li SJ, Fang XL, Fu SY (2001) Study on the technological conditions for producing gardenia blue by liquid fermentation. Food Sci Chin 22:46-48

Maki ML, Armstrong L, Leung KT, Oin W (2013) Increased expression of betaglucosidase A in Clostridium thermocellum 27405 significantly increases cellulase activity. Bioengineered 4:15-20

Sternberg D, Vijayakumar P, Reese ET (1977) beta-Glucosidase: microbial production and effect on enzymatic hydrolysis of cellulose. Can J Microbiol 23:139-147

Xiao YZ, Wang YP, Wang JM, Zhou L (2002) Studies on the production of gardenia blue pigment. Food Fermen Industries 28:37-41

Xu MM, Sun Q, Su R, Wang JF, Xu C, Zhang T et al (2008) Microbial transformation of geniposide in Gardenia jasminoides Ellis into genipin by Penicillium nigricans. Enzym Microb Technol 42:440-444

Yan SM, Shi DQ, Nong H, Wu G (2012) Predicting Km values of beta-glucosidases using cellobiose as substrate. Interdisciplinary Sci 4:46-53 
Yan SM, Wu G (2011) Prediction of Michaelis-Menten constant of betaglucosidases using nitrophenyl-beta-D-glucopyranoside as substrate. Protein Pept Lett 18:1053-1057

Yan SM, Wu G (2012) Exhausted jackknife validation exemplified by prediction of temperature optimum in enzymatic reaction of cellulases. Appl Biochem Biotechnol 166:997-1007

Yan SM, Wu G (2013) Prediction of turnover number of cellulose 1,4-betacellobiosidase. Protein Pept Lett 20:255-264

Yang D, Zhou M, Wei WX, Zhu HL, Fan XW (2012) Preparation of a genipin blue from egg protein and genipin. Nat Prod Res 26:765-769

Yang YS, Zhang T, Yu SC, Ding Y, Zhang LY, Qiu C et al (2011) Transformation of geniposide into genipin by immobilized beta-glucosidase in a two-phase aqueous-organic system. Molecules 16:4295-4304

You HJ, Ahn HJ, Ji GE (2010) Transformation of rutin to antiproliferative quercetin-3-glucoside by Aspergillus niger. J Agric Food Chem 58: 10886-10892

Zheng JP, Tang HY, Chen XJ, Yu BF, Xie J, Wu TC (2006) Construction of recombinant plasmid and prokaryotic expression in E. coli and biological activity analysis of human placenta arresten gene. Hepatobiliary Pancreatic Dis Int 5:74-79

\section{Publisher's Note}

Springer Nature remains neutral with regard to jurisdictional claims in published maps and institutional affiliations.

Ready to submit your research? Choose BMC and benefit from:

- fast, convenient online submission

- thorough peer review by experienced researchers in your field

- rapid publication on acceptance

- support for research data, including large and complex data types

- gold Open Access which fosters wider collaboration and increased citations

- maximum visibility for your research: over $100 \mathrm{M}$ website views per year

At BMC, research is always in progress.

Learn more biomedcentral.com/submissions 